\title{
Association of oxidative stress components with resistance to flax powdery mildew
}

\author{
Heba Mohamed ${ }^{1}$, Aly Abd EL-Hady², Mahmoud Mansour ${ }^{2}$ \& Abd El- rheem El-Samawaty ${ }^{2}$ \\ ${ }^{1}$ Department of Biological and Geological Sciences, Faculty of Education, Ain Shams University, Cairo, Egypt; ${ }^{2}$ Plant \\ Pathology Research Institute, Agricultural Research Center, Giza, Egypt
}

Author for correspondence: Heba Mohamed, e-mail: hebaibrahim79@yahoo.com

\begin{abstract}
Field trials were conducted in 2008/2009 and 2009/2010 growing seasons at Giza Agricultural Research Station to evaluate powdery mildew (PM) severity on nine flax cultivars. Tested cultivars could be classified into five distinct groups, i.e., highly susceptible (Corland and C.I. 2008), susceptible (Giza 7 and Marshall), moderately susceptible (Cass), moderately resistant (Dakota, Koto and Wilden) and resistant (Ottowa 770B). They showed considerable variation in PM severity ranging from 8.1 on Ottowa 770B to 97.0\% infected leaves/plant on Cortland. Total soluble proteins, total phenols, peroxidase, polyphenoloxidase, ascorbic acid, tocopherol and malondialdehyde were determined in infected leaves of the tested cultivars. Pearson's correlation coefficient was calculated to measure the degree of association between PM severity and each biochemical component. All components showed significant $(\mathrm{P}<0.05)$ or highly significant $(\mathrm{P}<0.01)$ negative correlation with $\mathrm{PM}$ severity except MDA, which showed positive correlation $(\mathrm{P}<0.01)$. The results of the present study suggest that phenols and MDA in infected leaves could be used to assist the screening of resistant plants at early stages of powdery mildew development.
\end{abstract}

Key words: Linum usitatissimum, Oidium lini, ascorbic acid, lipid peroxidation, peroxidase, polyphenoloxidase, tocopherol.

\section{INTRODUCTION}

Powdery mildew (Oidium lini Ŝkoric) of flax (Linum usitatissimum L.) is currently considered the most common, conspicuous, widespread, and easily recognized foliar disease of flax in Egypt. Flax is grown for both seeds and fibers in the Nile Delta, particularly in the northern governorates. This area is characterized by the prevalence of warm, wet weather during the late period of flax growing season. Such weather favors epiphytotic spread of the disease when virulent isolates of the causal fungus occur. Over the last two decades, the importance of this disease has increased probably due to the appearance and rapid distribution of new races capable of attacking the previously resistant cultivars (Aly et al., 1994). Currently, resistance is not available in the commercially grown flax cultivars in Egypt (Aly et al., 2002). Therefore, in years when environmental conditions favor the development of the disease, foliar application of fungicides has become the only commercially available management practice for its control (Aly et al., 1994).

Although the fungus causing powdery mildew on flax in other countries has been reported as Erysiphe polygoni DC. Ex Merat (Nyvall, 1981). In Egypt, it has not been observed in its perfect stage. Therefore, in the present work the fungus will be referred to its imperfect (conidial) stage, i.e. Oidium lini Škoric (Muskett \& Colhoun, 1947).
Extensive genetic variation in terms of $\mathrm{PM}$ resistance has been identified in some flax populations. For example, Prasad et al. (1988) evaluated 2822 linseed varieties for rust and PM resistance and could classify them according to the percentage of infected leaf area per plant. Only 24 of those lines were free from both rust and PM, and 17 showed multiple resistances (1-10\% infected leaf area/plant). In addition, 38 genotypes were free from rust and resistant to PM. Basandrai et al. (1994) evaluated 200 indigenous and exotic flax genotypes for resistance to PM under field conditions. Twenty-four genotypes were free from infection, and 12 genotypes were resistant to PM and also possessed desirable plant height for fiber flax. Mahto et al. (1995) found a significant variability among 26 flax genotypes in resistance to PM. Eleven had above average stability and seven of these had high yields. Of 43 flax introductions evaluated in a two-year outdoor pot experiment, Mansour et al. (2003) found that only three introductions showed satisfactory levels of resistance in both years. Some of the other introductions were resistant in only one year, which indicated that their performance lacked stability.

It has been suggested that a variety of compounds contained in plant cells are involved in resistance or susceptibility to infection by pathogens. Among these are proteins (Strange, 2003), phenols (Agrios, 2005), ascorbic 
acid (Vidyasekaran, 2008), tocopherol (Castle \& Day, 1984), peroxidase (Agrios, 2005), polyphenoloxidase (Agrios, 2005) and malondialdehyde as indicator of lipid peroxidation (Göbel et al., 2003).

No information about the biochemical basis of resistance or susceptibility of flax to PM is available. Therefore, the objective of the present study was to investigate if the previously mentioned biochemical components are associated with resistance of flax to PM.

\section{MATERIALS AND METHODS}

\section{Reactions of flax cultivars to PM}

Field trials were conducted in 2008/2009 and 2009/2010 growing seasons at Giza Agricultural Research Station to evaluate PM severity on nine flax cultivars. The experiments consisted of a randomized complete block design of three replications (blocks). Plots of $6 \mathrm{~m}^{2}(2 \mathrm{x} 3$ $\mathrm{m})$ consisted of ten rows spaced $20 \mathrm{~cm}$ apart. Seeds of each cultivar were sown by hand at a rate of $70 \mathrm{~g} /$ plot. Planting date was the first week of December. Flax cultivars were left for natural infection and disease severity was rated visually in the last week of April based on percentage of infected leaves/ plant in a random sample of 10 plants/ plot (Nutter et al., 1991). Disease severity was not rated based on percentage of infected leaf area because at this stage of disease development, surface of infected leaves was almost completely covered with fungal growth.

\section{Chemical analysis}

Random samples of infected leaves were used for chemical analysis at early stage of disease development when plants were 80 days old. At this age, the disease was in its detection threshold (Nutter et al., 1991). Samples were stored in deep freezer at $-30^{\circ} \mathrm{C}$ for two days. Biochemical components were determined as follows:

\section{Total phenols}

Soluble phenols in fresh samples were extracted according to Dihazi et al. (2003). $0.5 \mathrm{~g}$ of fresh samples weight were extracted with $80 \%$ cold methanol (v/v) for three times at $90^{\circ} \mathrm{C}$. The combined extract were collected and filtered through Whatman No.1 filter paper. After filtration, the filtrate was made up to $20 \mathrm{~mL}$ with cold methanol. A $0.5 \mathrm{~mL}$ volume of the extract was added to $0.5 \mathrm{~mL}$ folin-Cicalteu reagent and shacked well. The mixture was allowed to stand for $3 \mathrm{~min}$ and then one $\mathrm{mL}$ of saturated sodium carbonate solution $\left(25 \mathrm{~g} \mathrm{Na}_{2} \mathrm{Co}_{3}\right.$ were dissolved in $1000 \mathrm{~mL}$ distilled water at $70-80^{\circ} \mathrm{C}$ and cooled down and filtered) was added to the mixture and shaken vigorously. The mixture was allowed to stand for $60 \mathrm{~min}$. and then, the optical density was measured with a spectrophotometer at $725 \mathrm{~nm}$ UV-Vis. The quantity of total phenolic compounds was calculated according to the standard curve of gallic acid $(99.5 \%)$ and expressed as $\mathrm{mg} / 100 \mathrm{~g}$ fresh weight.

\section{Assay of peroxidase activity}

Two grams of fresh sample were homogenized either in cold phosphate buffer $(0.05 \mathrm{M}$ at $\mathrm{pH}$ 6.5). The homogenate was centrifuged at $1000 \mathrm{rpm}$ for 10 minutes. The pigments were removed from the supernatant by adsorbing on activated charcoal and filtered. The filtrate was completed to a known volume and used to determine enzymes and total soluble protein.

Peroxidase (EC 1.11.1.7) was assayed following the method of Kar \& Mishra (1976) with slight modification. Five $\mathrm{mL}$ of the assay mixture contained $300 \mu \mathrm{M}$ of phosphate buffer ( $\mathrm{pH} 6.8$ ), $50 \mu \mathrm{M}$ catechol, $50 \mu \mathrm{M} \mathrm{H}_{2} \mathrm{O}_{2}$ and $1 \mathrm{~mL}$ of crude enzyme extract was prepared. After incubation at $25^{\circ} \mathrm{C}$ for 5 minute, the reaction was stopped with the addition of $1 \mathrm{~mL}$ of $10 \% \mathrm{H}_{2} \mathrm{SO}_{4}$. The colour was read at $430 \mathrm{~nm}$ and the enzyme activity was expressed as enzyme activity/g fresh weight/hour.

\section{Assay of polyphenoloxidase activity}

Polyphenoloxidase (EC 1.14.18.1) was assayed following the method described by Kar \& Mishra (1976) with little modification; five $\mathrm{mL}$ of assay mixture containing $125 \mu \mathrm{M}$ of phosphate buffer (pH 6.8) and 100 $\mu \mathrm{M}$ pyrogallol were added to $1 \mathrm{~mL}$ of crude enzyme extract. After incubation at $25^{\circ} \mathrm{C}$ for $5 \mathrm{~min}$, the reaction was stopped with the addition of $1 \mathrm{~mL}$ of $10 \% \mathrm{H}_{2} \mathrm{So}_{4}$ the colour intensity was read at $430 \mathrm{~nm}$, and the enzyme activity was expressed as enzyme activity/g fresh weight/hour.

\section{Total soluble protein}

Alkaline tartarate reagent $20 \mathrm{~g}$ sodium carbonate and $0.5 \mathrm{~g}$ tartarate were dissolved in liter of $0.1 \mathrm{~N} \mathrm{NaOH}$. Ten $\mu \mathrm{L}$ of the protein sample were added to $5 \mathrm{~mL}$ of the working alkaline copper reagent, and was allowed to stand for $15 \mathrm{~min}$. at room temperature. The dilution folin reagent $(0.5 \mathrm{~mL})$ was then mixed immediately with the mixture; and allowed to stand $30 \mathrm{~min}$. at room temperature. The color intensity of samples was measured at $750 \mathrm{~nm}$. The total soluble protein content in the supernatant was determined according to Lowry et al. (1951) the quantity of total soluble protein was calculated according to the standard curve of Bovine Serum Albumin and expressed as $\mathrm{mg} / \mathrm{g}$ fresh weight.

\section{Ascorbic acid}

Two grams of fresh samples were ground in $6 \%$ trichloroacetic acid (TCA) and the extract filtered through filter paper and centrifuged at $1000 \mathrm{rpm}$ for $20 \mathrm{~min}$. The filtrate was made up to $10 \mathrm{~mL}$ with TCA. Ascorbic acid was determined as described by Mukherjee \& Choudhuri (1983). Four $\mathrm{mL}$ of the extract was mixed with $2 \mathrm{~mL}$ of $2 \%$ dinitrophenyl hydrazine (in acidic medium) followed by the addition of drop of $10 \%$ thiourea (in $70 \%$ ethanol). The mixture was boiled for $15 \mathrm{~min}$ in a water bath and after cooling to room temperature, $5 \mathrm{~mL}$ of $80 \%(\mathrm{v} / \mathrm{v}) \mathrm{H}_{2} \mathrm{SO}_{4}$ was added to the mixture at $0^{\circ} \mathrm{C}$ (in an ice bath) the absorbance was recorded at $530 \mathrm{~nm}$ using spectrophotometer. The 

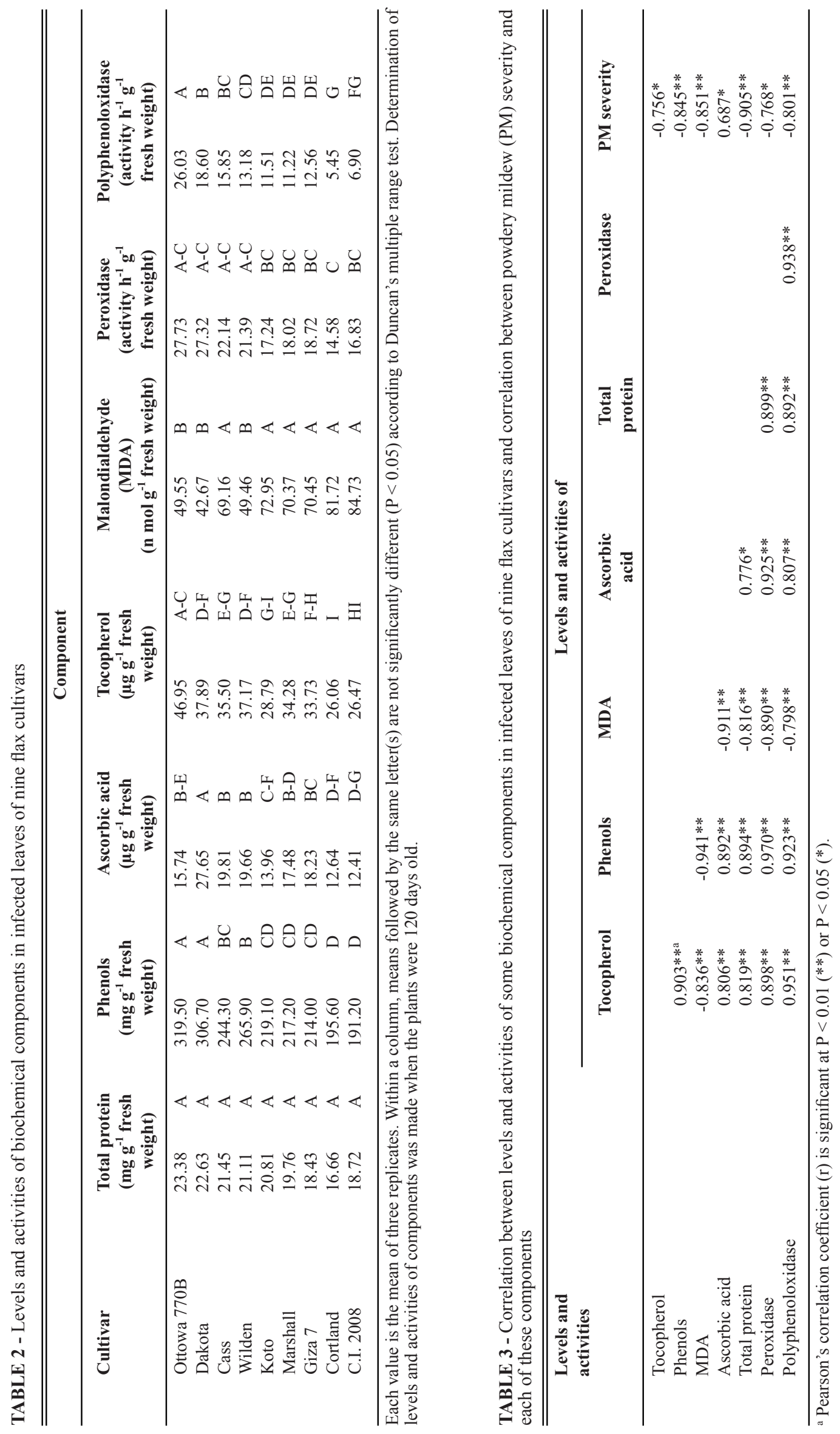
Pearson's correlation coefficient (r). However, one should keep in mind that the significant correlation does not necessarily imply causation (Gomez \& Gomez, 1984).

Tocopherol prevents the oxidation of unsaturated fatty acids in cell membrane, so, maintaining their structure (Daintith, 1996). Therefore, it seems reasonable to speculate that the increases in tocopherol levels in infected leaf tissues may enhance flax resistance to PM by protecting cell membrane from oxidative damage associated with infection.

It is well known that the fungitoxic effect of most phenolics is attributed mainly to their interaction with lipids or phospholipids, causing an increase in fungal membrane permeability, leakage of cell contents, and cytoplasm aggregation (Dallagnol et al., 2011). Thus, increases in the levels of post-infectional phenolic compounds in leaf tissues may enhance flax resistance against infection by PM. The negative association between phenolics and susceptibility to PM, as we have demonstrated herein, has been supported by findings of Gawande et al. (2002), Avtar et al. (2003), Rao et al. (2007) and Satisha et al. (2008).

The MDA produced during lipid peroxidation is an indicator of cellular damage. It is well known that lipid peroxidation in the plasma membrane of cell wall by reactive oxygen species is caused by the occurrence of any type of stress to the cells (Dallagnol et al., 2011). In our study, MDA was the only component, which showed positive correlation with PM severity. This result may suggest that the post-infectional lipid peroxidation plays an important role in determining susceptibility of flax to PM. The high levels of post-infectional lipid peroxidation, as indicated by the enhanced production of MDA, in highly susceptible cultivars, could cause an increase in flax membrane permeability that, in turn, may lead to more disease severity.

Many reports suggest that the antioxidant ascorbic acid is involved in suppression of defense genes. For example, ascorbic acid reduced the elicitor-inducible phenolic synthesis in rice (Velazhahan \&Vidhyasekaran, 1999) and tomato cells (Vera-Estrella et al., 1993). Ascorbic acid inhibited the oxidation of phenolics in epicotyls of Vigna angularis (Takahama, 1993) and spinach leaves (Takahama \& Oniki, 1992). It also inhibited the oxidation of coniferyl alcohol by peroxidase leads to synthesis of lignin, another important defense-related compound (Ye et al., 1990). Pastori et al. (2003) showed that many defense genes, particularly those that encode pathogenesis-related proteins were activated in Arabidopsis mutant deficient in biosynthesis of ascorbic acid. In this study, a negative correlation was observed between ascorbic acid content and PM severity. This finding may suggest that ascorbic acid is involved in activation of defense genes. However, no conclusive biological explanation is available for the discrepancy between our finding and those reported by the others.

Our results are in agreement with Ashry \& Mohamed (2012) who found that total soluble protein content in flax leaves infected with Odium lini Skoric increased significantly in resistant lines when compared with resistant parent but decreased significantly in susceptible lines when compared with resistant parent. In susceptible cultivars, powdery mildew fungi reduce plant protein because they take up amino acids from plants in order to grow biographically. So, plants cannot build up proteins properly. In contrast, the contribution of proteins in plant resistance to fungal infection is well documented in literature (Strange, 2003). We assessed proteins in infected flax leaves after the appearance of early disease symptoms. Therefore, it seems likely that the assessed proteins included both constitutive proteins and pathogenesis-related proteins, which are induced in response to pathogen attack. Constitutive protein has a role to play in plant defense through a variety of mechanisms. For instance, they may affect structural components of pathogen wall or interfere with synthesis of pathogen wall. They may also destabilize fungal membrane (Strange, 2003). On the other hand, pathogenesis-related proteins show strong antifungal activity. For example, some of them inhibit spore release and germination whereas others are associated with strengthening of the host cell wall and its outgrowths and papillae (Agrios, 2005).

The importance of peroxidase in disease resistance stems from its property to oxidize phenolic compounds to quinones and semiquinones, which are often more toxic to pathogens than the original phenols. Peroxidase not only oxidizes phenolics but also increases the rate of polymerization of such compounds into lignin-like substances, which are deposited in cell walls and papillae and interfere with the growth and development of the pathogen (Agrios, 2005). Direct antifungal effects of peroxidase on spore germination and mycelial growth have also been demonstrated (Joseph et al., 1998). Thus, it was reasonable to find a significant and negative correlation between peroxidase activity and PM severity.

Polyphenoloxidase (PPO) is an enzyme of broad distribution among plants. Most of the reports on PPO indicate a function to defend plants against pathogens. The mode of action proposed for PPO is based on its capacity to catalyze the hydroxylation of monophenols to diphenols and their oxidation to diquinones. The quinones formed may act in several ways leading to protection of plants (Melo et al., 2006). Thus, PPO showed a significant and negative correlation with PM severity. On the other hand, the correlation between phenolics and PM severity $(\mathrm{r}=$ $-0.845, \mathrm{P}<0.01)$ was greater than that between PPO and PM severity $(\mathrm{r}=-0.801, \mathrm{P}<0.01)$

These results suggest that flax resistance to PM may be related to the oxidative potential of phenolic composition of leaves rather than simply to a higher PPO activity (Melo et al., 2006).

Our results are in agreement with other reports, which showed a negative association between post-infectional activity of both peroxidase and PPO and susceptibility to PM in some hosts like garden pea (Kalia, 1998), mungbean 
(Gawande et al., 2002), fenugreek (Avtar et al., 2003), and grapes (Roa et al., 2007).

Phenols, MDA and proteins showed the highest correlation with PM severity. In practical terms, the high $r$ values mean that a primary selection to eliminate susceptible genotypes can be made relatively at early stage of growth after the appearance of the first visible symptoms. In this primary selection, only genotypes with high levels of phenols or low levels of MDA would be retained for further evaluation under field conditions or in the greenhouse. This could decrease the time and effort necessary for the development of resistant genotypes in breeding programs. However, this conclusion needs to be critically tested by evaluating more comprehensive samples and cultivars.

\section{REFERENCES}

Agrios GN (2005) Plant Pathology, $5^{\text {th }}$ ed. San Diego USA. Elsevier Academic Press.

Aly AA, Ashour AZA, El-Kady EAF, Mostafa MA (1994) Effectiveness of fungicides for control of powdery mildew of flax and effect of the disease on yield and yield components. Journal of Agriculture Science, Mansoura University 19:4383-4393.

Aly AA, Amna H, El-Sweify H, Mansour MTM (2002) Evaluation of some flax genotypes for powdery mildew resistance under greenhouse and field conditions. Journal of Agriculture Science, Mansoura University 27:7323-7333.

Ashry NA, Mohamed HI (2012) Impact of secondary metabolites and related enzyme in flax resistance and/or susceptibility to powdery mildew. African Journal of Biotechnology 11:10731077.

Avtar R, Rathi AS, Jatasra DS, Joshi UN (2003) Changes in phenolics and some oxidative enzymes in fenugreek leaves due to powdery mildew infection. Acta Phytopathologica et Entomologica Hungarica 38:237-244.

Basandrai D, Basandrai AK, Sethi SG, Bhater S (1994) Evaluation of flax (Linum usitatissimum) genotypes for multiple disease resistance. Indian Journal of Agriculture Sciences 64:704-707.

Castle AJ, Day AW (1984) Isolation and identification of $\alpha$-tocopherol as an inducer of the parasitic phase of Ustilago violacea. Phytopathology 74:1194-1200.

Daintith J (1996) A Dictionary of Chemistry, $3^{\text {rd }}$ ed. Oxford UK. Oxford University Press.

Dallagnol LJ, Rodrigues FA, DaMatta FM, Mielli MVB, Pereira SC (2011) Deficiency in silicon uptake affects cytological, physiological, and biochemical events in the rice-Bipolaris oryzae interaction. Phytopathology 101: 92-104.

Dihazi AD, Jaiti F, Zouine J, El-Hassni M, El-Hadrami I (2003) Effect of salicylic acid on phenolic compounds related to date palm resistance to Fusarium oxysporum f.sp. albedinis. Phytopathologia Mediterranea 42:9-16.

Gawande VL, Patil JV, Naik RM, Kale AA (2002) Plant biochemical defense against powdery mildew (Erysiphe polygoni DC) disease in mungbean (Vigna radiate (L.) Wilczek). Journal of Plant Biology 29:337-341.
Göbel C, Feussner I, Rosahl S (2003) Lipid peroxidation during the hypersensitive response in potato in the absence of 9-lipoxygenases. Journal of Biology Chemistry 278:52834-52840.

Gomez KA, Gomez AA (1984) Statistical Procedures for Agricultural Research, $2^{\text {nd }}$ ed. New York USA. John Wiley and Sons.

Hawk PB, Oser BL, Summerson WH (1954) Practical Physiological Chemistry. New York NY, USA. McGraw-Hill.

Heath RL, Packer L (1968) Photoperoxidation in isolated chloroplasts. I. Kinetics and stoichiometry of fatty acid peroxidation. Archives of Biochemistry and Biophysics 125:189198.

Joseph LM, Koon TT, Man WS (1998) Antifungal effects of hydrogen peroxide and peroxidase on spore germination and mycelial growth of Pseudocercospora species. Canadian Journal of Botany 76:2119-2124.

Kalia P (1998) Enzymic association of powdery mildew resistance in garden pea. Vegetable Science 25:166-168.

Kar M, Mishra D (1976) Catalase, peroxidase, and polyphenoloxidase activity during leaf senescence. Plant Physiology 57:315-319.

Lowery OH, Rosembrough NJ, Farr AL, Randall RJ (1951) Protein measurement with the folin phenol reagent. Journal of Biology Chemistry 193:267-275.

Mahto JL Choudhary U, Singh SN (1995) Stability and genetic divergence in linseed (Linum usitatissimum) under rainfall situation. Indian Journal of Agriculture Sciences 65:602-604.

Mansour MTM, Ashry NA, Aly AA, Zayed SME (2003) Evaluation of some flax plant introductions for powdery mildew resistance under natural infection conditions. Journal of Agriculture Science, Mansoura University 28:2689-2697.

Melo GA, Shimizu MM, Mazzafera P (2006) Polyphenoloxidase activity in coffee leaves and its role in resistance against the coffee leaf miner and coffee leaf rust. Phytochemistry 67:277-285.

Mukherjee SP, Choudhuri MA (1983) Implications of water stress induced changes in the levels of endogenous ascorbic acid and hydrogen peroxide in Vigna seedlings. Physiologia Plantarum 58:166-170.

Muskett AE, Colhoun J (1947) The Diseases of the Flax Plant. Belfast UK. Northern Ireland Flax Development Committee.

Nutter FW, Teng PS, Shoks FM (1991) Disease assessment terms and concept. Plant Disease 75:1187-1188.

Nyvall RF (1981) Field Crop Diseases Handbook. Westport USA. AVI Publishing Company.

Pastori GM, Kiddle G, Antoniw J, Bernard S, Veljovic-Jovanovic S, Verrier PJ, Noctor G, Foyer CH (2003) Leaf vitamin C contents modulate plant defense transcripts and regulate genes that control development through hormone signaling. Plant Cell 15:939-951.

Prasad R, Rai M, Kerkhi SA (1988) Resistance of linseed (Linum usitatissimum) germplasm to rust (Melampsora lini) and powdery mildew (Oidium lini). Indian Journal of Agriculture Sciences 58:548-549.

Rao KD, Jindal PC, Singh R, Srivastava GC, Sharma RC (2007) Biochemical and genetical studies in grape germplasm for powdery 
mildew (Uncinula necator) disease resistance. Agricultural Science Digest 27:235-238.

Satisha J, Doshi P, Adsula PG (2008) Influence of rootstocks on changing the pattern of phenolic compounds in Thompson seedless grapes and its relationship to the incidence of powdery mildew. Turkish Journal of Agriculture and Forestry 32:1-9.

Strange RN (2003) Introduction to Plant Pathology. West Sussex UK. John Wiley and Sons.

Takahama U (1993) Regulation of peroxidase dependent oxidation of phenolics by ascorbic acid: different effects of ascorbic acid on the oxidation of coniferyl alcohol by the apoplastic soluble and cell wall bound peroxidase from epicotyls of Vigna angularis. Plant Cell Physiology 34:809-817.

Takahama U, Oniki T (1992) Regulation of peroxidase-dependent oxidation of phenolics in the apoplast of spinach leaves by ascorbate. Plant Cell Physiology 33:379-387.
Velazhahan R, Vidhyasekaran P (1999) An elicitor of the rice sheath blight pathogen Rhizoctonia solani exhibits dual function: elicitation and suppression of tissue necrotization in rice. Acta Phytopathologica et Entomologica Hungarica 34:187-198.

Vera-Estrella R, Blumwald E, Higgins VJ (1993) Non-specific glycopeptides elicitor of Cladosporium fulvum: evidence for involvement of active oxygen species in elicitor-induced effects on tomato cell suspensions. Physiological and Molecular Plant Pathology 42:9-22.

Vidhyasekaran P (2008) Fungal Pathogenesis in Plants and Crops: Molecular Biology and Host Defense Mechanisms, $2^{\text {nd }}$ ed. Boca Raton USA. CRC Press.

Ye XS, Pan SQ, Kuc J (1990) Activity, isozyme pattern, and cellular localization of peroxidase as related to systemic resistance of tobacco to blue mold (Peronospora tabacina) and to tobacco mosaic virus. Phytopathology 80:1295-1299.

TPP 2012-0036 - Received 12 June 2012 - Accepted 9 August 2012 Section Editor: Marciel J. Stadnik 